\title{
Canopy Development and Spray Deposition in Highbush Blueberry
}

\author{
Gary VanEe, ${ }^{1}$ \\ Richard Ledebuhr, ${ }^{2}$ \\ Eric $\mathrm{H}$ anson, ${ }^{3} \mathrm{~J}$ im $\mathrm{H}$ ancock, ${ }^{4}$ \\ and D onald C. Ramsdell ${ }^{5}$
}

AdDITIONAL INDEX WORDS. captan, sprayer, Vaccini um corymbosum, fungicide, insecticide

\begin{abstract}
Summary. M ost highbush blueberries (Vaccinium corymbosum L.) in M ichigan are treated annually with fungicides and insecticides with several types of sprayers. The goal of this study was to determine how sprayer type, pruning severity, and canopy development interact to affect spray deposition patterns. D eposition was measured as the percentage of the surface area of card targets that was covered following applications of black dye. Light measurements indicated that the canopy of blueberry bushes, regardless of pruning treatment, closed by the middle of June, and light levels within the canopy changed little from then until fruit harvest in August. A standard airblast sprayer that pushed spray up and
\end{abstract}

\footnotetext{
Acknowledgment ismadeto theM ichigan Agricultural Experiment Station for support of this work. The authors thank Steven Paul for his cooperation and assistance during this project. The cost of publishing this paper was defrayed in part by the payment of page charges. U nder postal regulations, this paper therefore must behereby marked adverti sement solely to indicate this fact.

${ }^{1}$ Professor, D epartment of Agricultural Engineering, Department of Agricultural Engineering, Michigan State U niversity, East L ansing, M I 48824-1325.

${ }^{2}$ Specialist, D epartment of Agricultural Engineering, D epartment of Agricultural Engineering, $M$ ichigan State U niversity, East Lansing, M I 48824-1325.

${ }^{3}$ Professor, D epartment of $\mathrm{H}$ orticulture, D epartment of $\mathrm{H}$ orticulture, $\mathrm{M}$ ichigan State $\mathrm{U}$ niversity, East $\mathrm{L}$ ansing, M I 48824-1325 (to whom reprint requests should be addressed; e-mail address: hansone@msu.edu).

${ }^{4}$ Professor, D epartment of $\mathrm{H}$ orticulture, D epartment of $\mathrm{H}$ orticulture, M ichigan State U niversity, East L ansing, M I 48824-1325.

${ }^{5}$ Professor, D epartment of Botany and Plant Pathology (retired), D epartment of Botany and Plant Pathology, M ichigan State U niversity, East Lansing, M I 488241325.
} 
through bushes provided acceptable deposition in all parts of the canopy early in the season, but later in the season, coverage was poor in the top and sides furthest from the sprayer. An above-row sprayer with fan-driven micronozzles also provided acceptable coverage throughout the bushes early in the season, but once the canopy had closed, coverage was poor in the bottom of the bush. Both sprayers were operated in bushes receiving light, moderate, and heavy pruning. The more severe pruning regimes increased the amount of spray deposited from the above-row sprayer, but not from the airblast sprayer.

$\mathrm{M}$

ost commercial plantings of highbush blueberry (Vaccinium cor ymbosum) in the U nited States are treated each year with fungicides $(88 \%$ of acreage) and insecticides ( $83 \%$ of acreage) (U.S. D epartment of Agriculture, N ational Agricultural Statistics Service, 1998). Pesticides are applied to commercial blueberries in $M$ ichigan with fixed-wing aircraft and ground sprayers. Airplanes treat acreage rapidly (high field capacity) and are considered particularly useful prior to harvest when ground equipment can bruise fruit or knock berries off peripheral branches. A limitation of aerial spraying is that calm conditions are needed to minimize off-target drift and provide acceptabledeposition uniformity. In addition, aircraft are too expensivefor individual producersand commercial application servicesare not available in some areas. Cannon sprayers that project spray across the top of several blueberry rows are al so popular because they have a high field capacity, and since fewer passes through the field are required, the potential for mechanical damage to fruit is minimized. H owever, cannon sprayersmay result in irregular deposition and/ or off-target drift during windy conditions. Conventional airblast sprayers that propel spray up and through bushes are also common in M ichigan. Airblast sprayers may provide thorough coveragebut requirelonger treatment times (lower field capacity). Field capacity may be increased by driving airblast sprayers down every second or third row middle, but uniformity of coverage may be sacrificed. An aboverow sprayer that utilizes multiple fans and nozzles was developed recently by agricultural engineersat $M$ ichigan State U niversity, and this concept is now available commercially. In choosing application technology, growers also must consider the equipment costs relative to the size of their plantings, and the availability of contract application services in their area.

Theimportance of deposition uniformity and field capacity may depend on the insect pest or pathogen being targeted and each grower's situation. $U$ niform deposition may be most important for nonsystemic pesticides, such as captan, which is a protectant chemical requiring thorough coveragewithin the canopy for control of fruit-rotting fungi. Even when recommended fungicideprogramsarefollowed, fruit rots caused by Colletotrichum acutatum J.H . Simmonds) A Iternaria $\mathrm{N}$ ees, and Botrytiscinerea Pers.:Fr. can be prevalent in $\mathrm{M}$ ichigan blueberries ( $\mathrm{H}$ anson et al., 1999). D eposition uniformity may be less critical for control of mobile insect pests such as the blueberry maggot fly ( $R$ hagoletis mendax Curran), which may contact insecticide deposits even if deposition is not uniform. $\mathrm{H}$ igh field capacity provides greater flexibility in application timing. G rowers treating large areas with low field capacity application technology may need to begin treating early or treat when weather conditions are not optimal to be sure to cover all acreage.

Although spray deposition patterns have been studied in tree fruit and some field crops ( $\mathrm{H}$ all, 1991; $\mathrm{H}$ offman and Salyani, 1996; Kirk et al., 1992), reports of similar studies on blueberries could not be found. The highbush blueberry is a multistemmed, deciduous shrub that grows 1.2 to $3.0 \mathrm{~m} \mathrm{(4} \mathrm{to} 10 \mathrm{ft}$ ) in height. Pesticidesareapplied to M ichigan blueberries before leaves emerge through the harvest period when theleaf canopy isfully developed. D eposition patterns likely change as the blueberry canopy develops, similar to the way apple tree canopies affect spray deposition patterns (Ferree and H all, 1980). Some blueberrygrowershaveintuitively tried to compensate for canopy development by driving airblast sprayers down every third or fourth row middle early in the season, and every second row middle later in the season. Although regular, moderate pruning appears to optimize yields and berry size (Siefker and $H$ ancock, 1987), growers vary in their severity and frequency of prun- ing, so canopy densities in commercial fields vary widely. Growers may need to consider their application equipment and operation, pruning practices, and canopy development in order to optimize spray coverage.

The objectives of this work were to 1) describe the deposition patterns of two types of ground sprayers and 2) determinehow deposition patternsand light penetration areaffected by canopy development under different pruning regimes.

\section{Materials and methods}

The study site was a 40 year-old commercial planting of the 'J ersey' in M uskegon, M ich. Bushes were spaced

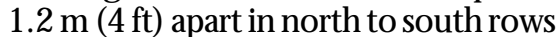
$3 \mathrm{~m}$ (10 ft) apart. Three pruning treatments (light, moderate, heavy) were imposed as follows. In M arch 1995, $20 \%$ of the largest canes were removed from bushes in the heavy pruning plots only. In M arch 1996, 20\%of the largest canes were removed from the moderate pruning plots, and an additional $20 \%$ were removed from the heavy pruning plots. Light pruning plots were not pruned. Pruning plots were five rows wideand 15 busheslong, and replicated three times in a randomized completeblock design. The number of canes in different diameters at a height of 10 to $20 \mathrm{~cm}$ (4 to 8 inches) above the crown was recorded on two bushes per plot in M ay, 1996 in describe relative differences in canopy densities.

Light measurements were taken on $28 \mathrm{M}$ ay (first open flowers), $6 \mathrm{~J}$ une (early bloom), 12 June (full bloom), 27 June (petal fall), 19 July [0.5-cm (0.2-inch) green fruit], and 22 Aug. (first harvest), 1996 with $1 \mathrm{~m}(3.3 \mathrm{ft}$ ) long Line Q uantum sensor ( $L I-C O R$, Lincoln, Neb.) inserted horizontally into each bush at $1 / 3,1 / 2$, and $2 / 3$ the distance from the top of the canopy. $M$ easurements were taken in two bushes in adjacent rows in the middle of each plot. Full sun readings were taken beside each bush, and light intensity was calculated as a percentage of the full sun reading.

Spray deposition patterns were studied by spraying a $4 \mathrm{~g} \cdot \mathrm{L}^{-1}(0.4 \%)$ solution Black Shade " $R$ " dye (WarnerJenkinson Co., St. Louis, M o.) and measuring coverage on card targets. Each target consisted of a $5 \mathrm{~cm}(2$ inch) diameter plastic disc holding four alligator clips radiating out from the edge. Four $2.5 \times 10.2 \mathrm{~cm}(1 \times 4$ inch) 
white kromcoat cards were clipped to each target. Targets were placed in four positions within bushes: 1) bottom [0.6 to $1.0 \mathrm{~m}$ ( 2 to $3 \mathrm{ft}$ ) height in center of canopy], 2) top of canopy, 3) west side at height of 1.0 to $1.5 \mathrm{~m} \mathrm{(3}$ to $5 \mathrm{ft}$ ), and 4) east side at the same height. Targets were clipped to branches in a random orientation in the same two bushes used for the light measurements. After the dye solution was sprayed and the cards had dried, the cards were placed in plastic bags, and later read with computer imaging software (O ptimas Imaging Corp., Edmonds, Wash.) that measured the percentage of the surface area that was covered with dye. Sixteen measurements were made per target (two per surface on four cards). The mean of 16 measurements was calculated for each target. Coverage usually varied greatly depending on the orientation of surfaces relative to the sprayer. A coefficient of variation wascalculated for the 16 measurements per target to illustrate the uniformity of coverage.

This system was used to study the spray deposition pattern sof two sprayers on $13 \mathrm{M}$ ay, $29 \mathrm{M}$ ay, $3 \mathrm{~J}$ uly, and 11 July 1996. An Agtec (Ag-Chem, $M$ innetonka, $M$ inn.) three-point hitch airblast sprayer (Fig. 1) was tested at a spray volume of $187 \mathrm{~L} \cdot \mathrm{ha}^{-1}$ (20 gal/ acre). The airblast sprayer was driven every other row middle at $1.5 \mathrm{~m} \cdot \mathrm{s}^{-1}$, (3.4 miles/ h) and had an estimated field capacity of $3.2 \mathrm{ha} \cdot \mathrm{h}^{-1}$ ( 7.9 acre/ h). The target bushes were in rows three and four of the five row-wide pruning plots, and the airblast sprayer was driven between rowstwo and three, and back between rows four and five. Average coverage was calculated between the two target bushes for the top and bottom of the bushes, and for the sides nearest to and farthest from the sprayer pass.

D eposition patterns of an aboverow sprayer (Fig. 2) were also studied on thesamedays. Theabove-row sprayer was constructed by agricultural engineers at $M$ ichigan State $U$ niversity, and wassimilar to the Proptec machinemarketed by Ledebuhr Industries (Bath, $M$ ich.). T he sprayer boom covered four rows (two nozzle/ fans units per row), and delivered a spray volume of 94 $\mathrm{L} \cdot \mathrm{ha}^{-1}$ (10 gal/ acre). The above-row sprayer was driven every fourth row middle at $1.5 \mathrm{~m} \cdot \mathrm{s}^{-1}$ giving a field capacity of $6.7 \mathrm{ha}^{-1}$ (16.5 acres/ h). The nozzle/ fan assemblies were positioned about $1 \mathrm{~m}$ apart along the boom, and were oriented facing downward at roughly $10 o^{\prime}$ clock and $2 o^{\prime}$ clock positions about $1 \mathrm{~m}(3.3 \mathrm{ft}$ ) above the plants. The front fan was angled about 20 degreesforward toward the center of the row, while the back fan was angled 20 degrees rearward towards the center of the row. D uring the deposition tests, the above-row sprayer was driven between rows three and four of the pruning plots, and thetarget busheswerethe sameasthoseused for theairblast sprayer (rows three and four).
A third study was conducted to compare deposition patterns when the airblast sprayer was driven down each row middle or every other middle. Targetswere placed in the samepositionsin thesame bushesfor each run. Flow rates were changed when every row middle was sprayed so that the spray volume was the same [187 L·ha-1 (20 gal/ acre)]. Comparisons were made on 13 May (budbreak) and 14 June (full bloom).

$D$ ata were analyzed by SAS computer software (SAS Institute, Cary,

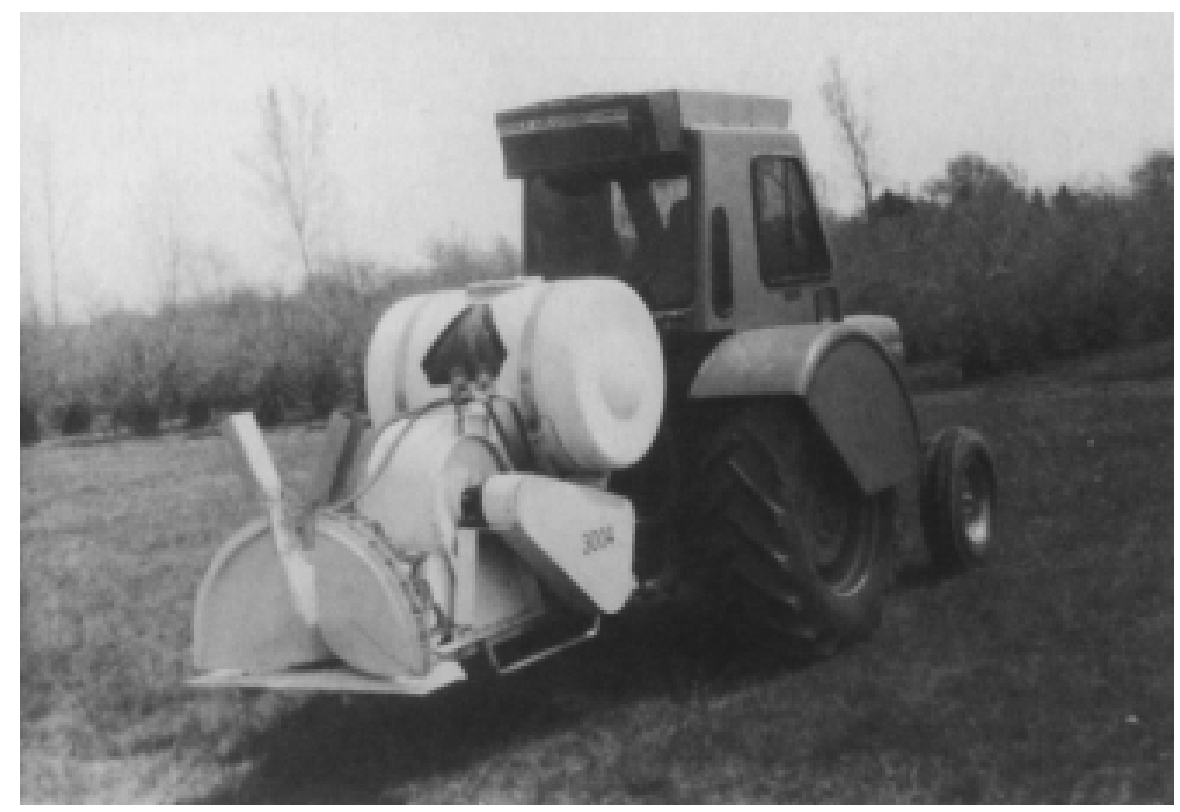

Fig. 1. Conventional airblast sprayer used in spray deposition studies.

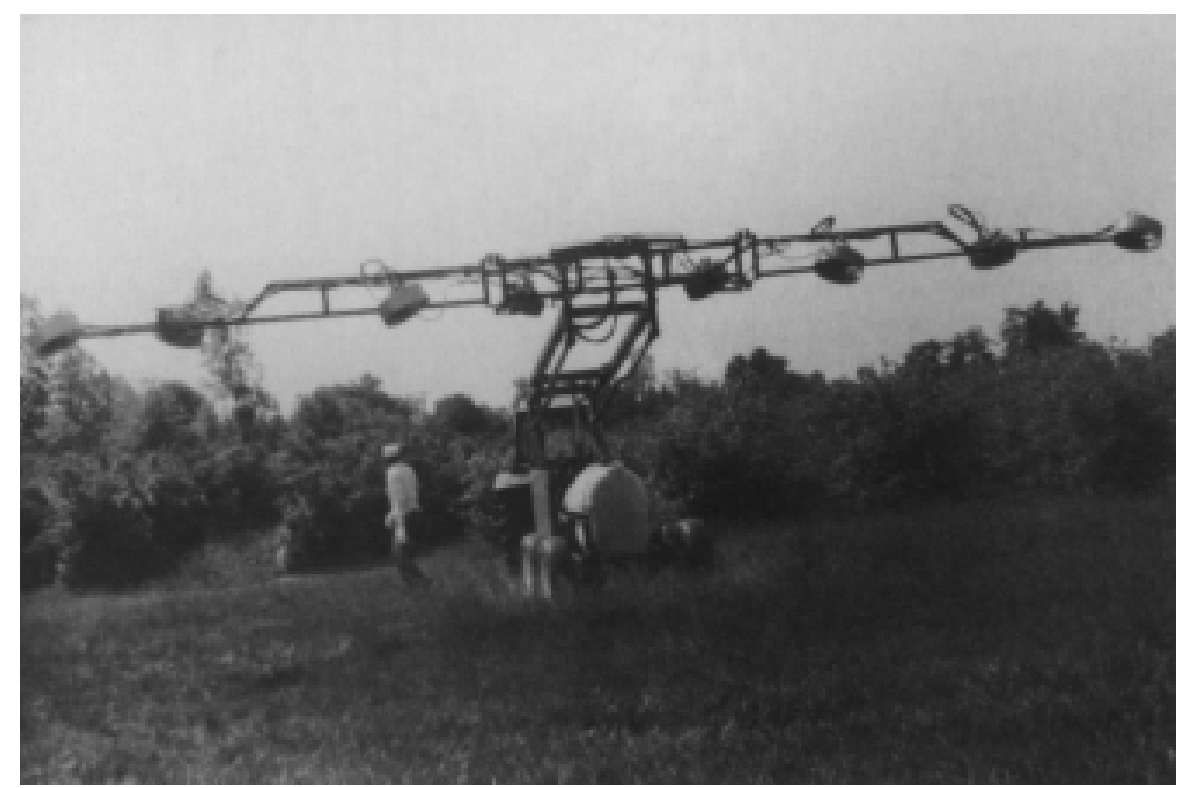

Fig. 2. Above-row sprayer used in spray deposition studies. 
T able 1. E ffect of pruning on the number of canes in different diameter size categories in 'J ersey' bushes in M ay, 1996.

\begin{tabular}{lllcccc}
\hline \multirow{2}{*}{$\begin{array}{l}\text { Pruning } \\
\text { treatment }\end{array}$} & $\begin{array}{l}\text { Total } \\
\text { canes/ } \\
\text { bush }\end{array}$ & \multicolumn{5}{c}{$\begin{array}{c}\text { Canes in diameter }\left(\mathbf{c m}^{2}\right) \text { categories } \\
\text { (\%) }\end{array}$} \\
\cline { 2 - 7 } & $41.9 \mathrm{a}^{\mathrm{y}}$ & $36 \mathrm{0.6}$ & $\mathbf{0 . 6 - 1 . 3}$ & $\mathbf{1 . 3 - 1 . 9}$ & $\mathbf{1 . 9 - 2 . 5}$ & $>\mathbf{2 . 5}$ \\
\hline Light & $37.4 \mathrm{ab}$ & $46 \mathrm{~b}$ & 41 & $14 \mathrm{a}$ & 7 & 1 \\
M oderate & $34.9 \mathrm{~b}$ & $42 \mathrm{ab}$ & 43 & $11 \mathrm{ab}$ & 3 & 0 \\
Heavy & & & $9 \mathrm{~b}$ & 5 & 1 \\
\hline
\end{tabular}

$22.5 \mathrm{~cm}=1$ inch.

YM eans in columns within each year separated by LSD $(P=0.05)$. F test was not significant if means are not followed by letters.

T able 2. E ffect of pruning on light levels in different positions in 'Jersey' blueberry canopies. Data are means of measurements on six dates between 28 May and 22 Aug. 1996.

\begin{tabular}{lccc}
\hline Pruning & \multicolumn{3}{c}{ Light (\% of full sun) } \\
\cline { 2 - 4 } treatment & Bottom third & Middle & Top third \\
\hline Light & $7 \mathrm{a}^{2}$ & $9 \mathrm{a}$ & $27 \mathrm{a}$ \\
M oderate & $12 \mathrm{~b}$ & $20 \mathrm{~b}$ & $41 \mathrm{~b}$ \\
H eavy & $13 \mathrm{~b}$ & $18 \mathrm{~b}$ & $48 \mathrm{C}$ \\
\hline
\end{tabular}

${ }^{2 M}$ eans in columns separated by LSD $(P=0.05)$.
N.C.). Light measurements and percent deposition data collected over time were analyzed by AN OVA as a split-split plot, with time, pruning, and position in the bush constituting the main plot, sub plot, and sub-sub plot, respectively. D ata from the comparison of alternate row to every row middle spraying with the airblast sprayer were analyzed as the same design, with time, spray application (alternate or every row), and position as the main plots, split plots and splitsplit plots, respectively.

\section{Results and discussion}

Pruning decreased the total number of canes and the percentages in the intermediate size category, and increased the percentage of canes in the smaller size categories, (T able 1). Although the optimum number and age of canes in 'J ersey' bushes hasnot been clearly defined, based on commercial standards, thelight pruning plots were in need of pruning in 1996, whereas the canopy densities in the moderate and heavy pruning plots were considered acceptable.

The AN O VA for light levelsindicated that the interactions of position in the canopy (PO) and time (T), and pruning treatment $(P R)$ and $P O$, were significant at the $P<0.01$ level, whereas the three-way interaction of $\mathrm{PO} \times \mathrm{PR}$ $\times T$ wasnot significant. Both moderate and heavy pruning increased light levels in all three positions in the canopy, relative to the light pruning treatment
(Table 2). Pruning increased light levelsin different positions in the canopy, with the most consistent differences in the upper third of the bush (Table 2). Light levels in the top, middle, and bottom of the canopy decreased as the leaf canopy developed between the time of first open flowers and petal fall, but changed little between petal fall and harvest (Fig. 3). H ighbush blueberries usually exhibit more than one flush of shoot growth, but the elongation of shootsfrom thefirst flush ceases
4 to 5 weeks after bloom ( $G$ ough et al., 1978). Light readings indicated that the canopy of these bushes had restricted light penetration by morethan $90 \%$ in the lower $2 / 3$ of the bush by petal fall, about 1 to 2 weeks after full bloom. Although additional shoot light penetration was not further reduced. As fruit increased in size after petal fall, their weight often pullscanes down. This may have counteracted further shading from continued growth of leaves and shoots.

A nalysis of the spray deposition from the airblast and the above-row sprayers over time indicated significant $(P<0.001)$ interactions of $P O$ and $T$, and $P R$ and $P O$, but the threeway interaction of $T, P R$, and $P O$ was not significant. The above-row sprayer resulted in thorough coverage throughout the bush on $13 \mathrm{M}$ ay (pink bud stage) and $29 \mathrm{M}$ ay (first bloom) (Fig. 4). By 3 July (late petal fall) and growth clearly occurred after thistime,

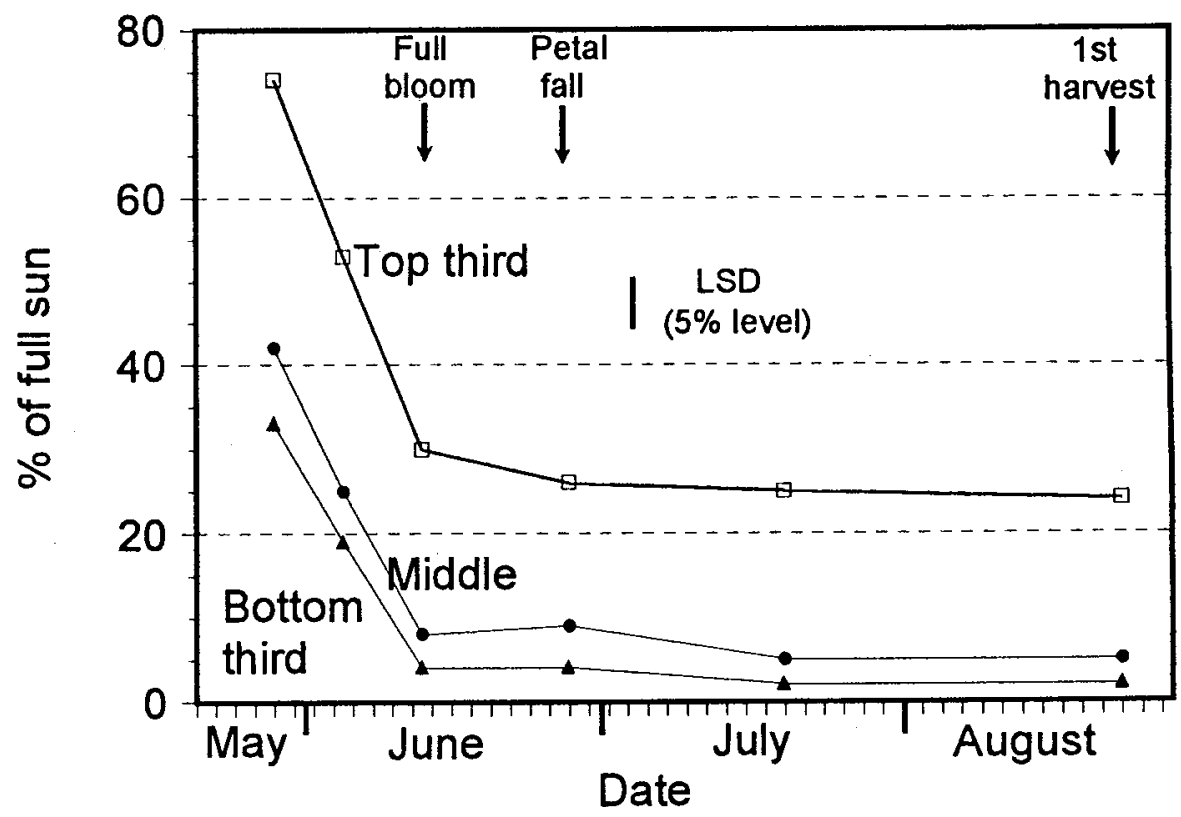

Fig. 3. Changes in light levels (percent of full sun) in the top third, middle, and bottom third of 'J ersey' blueberry canopies between the time of first open flowers and first fruit harvest. D ata are means across three pruning treatments. 

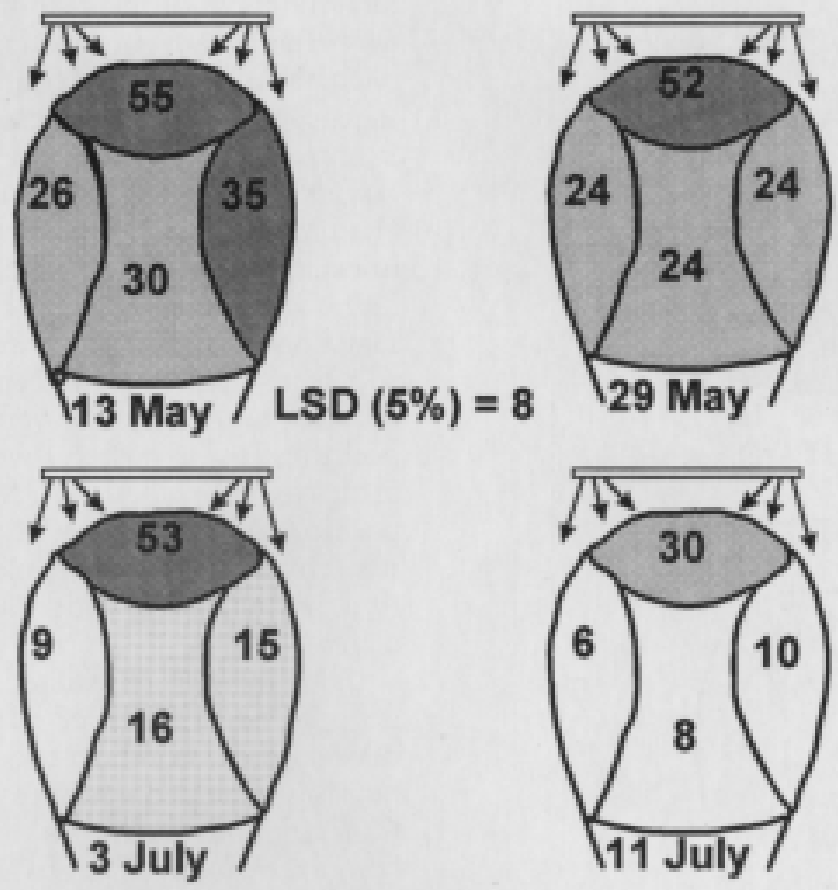

Fig. 4. Spray coverage (percent of surface area of card targets) in different positions in 'J ersey' blueberry canopies following treatment with an above-row sprayer on four dates between 13 May (pink bud) and 11 J uly (green fruit). D ata are means across three pruning treatments. LSD value refers to comparisons between dates and positions.
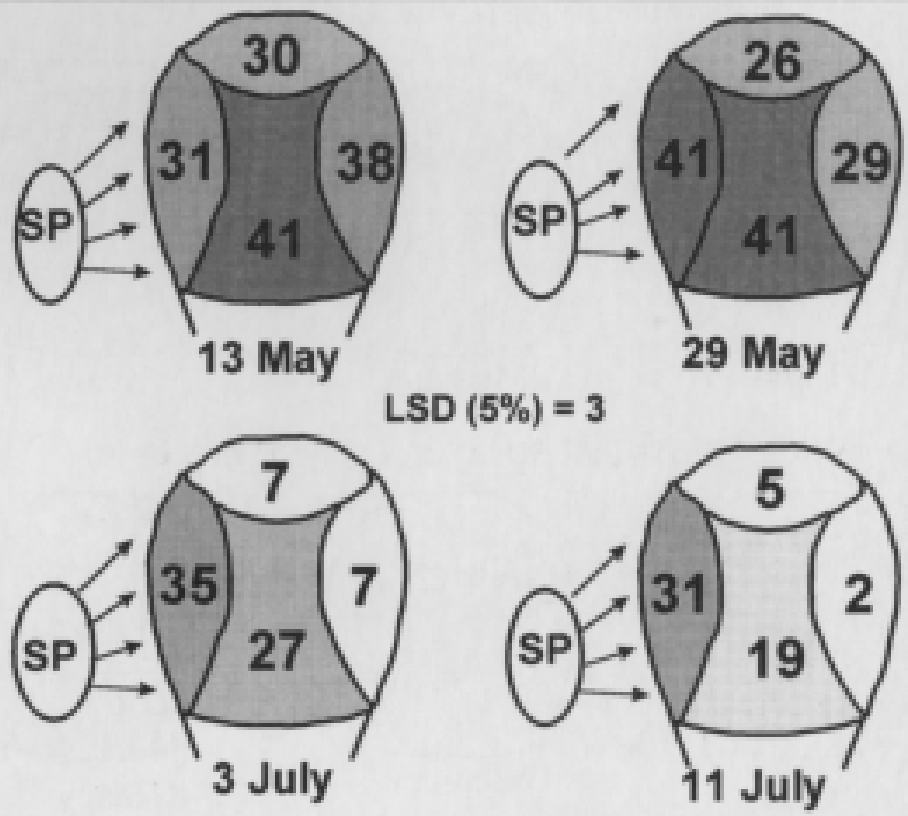

Fig. 5. Spray coverage (percent of surface area of card targets) in different positions in 'J ersey' blueberry canopies following treatment with an airblast sprayer (SP) on four dates between $13 \mathrm{M}$ ay (pink bud) and $11 \mathrm{~J}$ uly (green fruit). D ata are means across three pruning treatments. LSD value refers to comparisons between dates and positions.
11J uly, coveragewaspoor on thesides and in the bottom of the bush, while that in the top of the bush remained high (Fig. 4). D riving the airblast sprayer down alternate row middles resulted in thorough coverage throughout the bush on $13 \mathrm{M}$ ay and $29 \mathrm{M}$ ay (Fig. 5). O n 3 J ulyand 11 J uly, coverage was poor on the top and the side farthest from the sprayer, while coverage on the side facing the sprayer remained high (Fig. 5).

The airblast sprayer operated in every row middle resulted in thorough coverage in all parts of the bush, whether sprayed on $13 \mathrm{M}$ ay or $14 \mathrm{~J}$ une (Fig. 6). In contrast, alternate row middle spraying with the same sprayer resulted in thorough coverage on 13 $M$ ay, but poor coverage on the far side of the bush when sprayed at full bloom (14 June) (Fig. 6). Whereas driving airblast sprayers between every row provides excellent coverage, acreage can only be treated at half the speed of alternate row middle spraying. Also, every row middle spraying may not be practical for large bushes close to harvest because berries on overhanging canes may be knocked to the ground or bruised.

Theimpact of pruning severity on spray coverage with the two sprayers is illustrated in Fig. 7. In general, more severe pruning increased coverage in the areas of the canopy receiving lower overall coverage (e.g., bottom and sides with the above-row sprayer, and the top and far side with the airblast sprayer). Pruning tended to have less effect in positionswhere overall coveragewashigh (e.g., top of bush with the above-row sprayer, and bottom and near side with the airblast sprayer).

Spray coverage varied considerably between the 16 measurements on each target. Typically, readings varied from $10 \%$ to $90 \%$ coverage within a target, presumably due to the orientation of the surfaces relative to the spray source. The uniformity of coverage was assessed by comparing the coefficients of variation (cv) of the 16 measurements within each 4-card target (Table 3). The cvs were lowest with both sprayers early in the season. Targets closest to the spray source ( top for the above-row sprayer, near side for the airblast sprayer) had lower cvsthan targetsin other canopy positions. Pruning reduced the cvs for the above-row sprayer, but not for theairblast sprayer.

The relationships between the 


\section{Every row middle spraying}

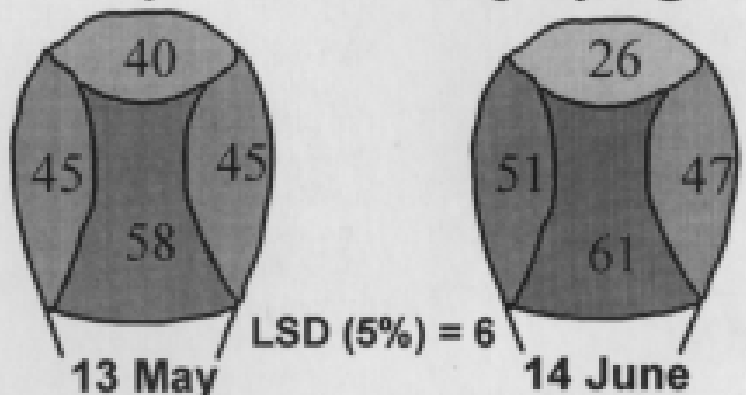

\section{Alternate row middle spraying}

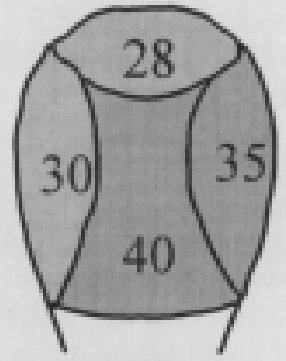

13 May

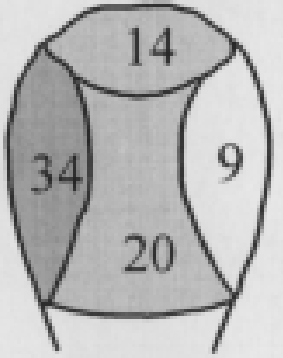

14 June
$\mathrm{N}$ onsystemic fungicides, such as captan, function by protecting surfaces from fungal infection. Captan is applied to control fungal fruit rots such as those caused by Colletotrichum acutatum (anthracnose ripe rot), A Iternaria sp., and Botrytis cinerea (Ramsdell, 1989). These fungi can infect individual flowers or developing berries (Bristow and Windom, 1998; $\mathrm{H}$ artung et al., 1981; R amsdell, 1992), so effective control with captan likely requires high overall coverage in all positions in the bush, as well as uniform coverage of all surfaces in each position (low cv). Systemic pesticides may compensate for irregular deposition by being redistributed within the plant.

Thesestudiesillustrated that spray deposition isgreatly affected by canopy development. U niform coverage may be easily obtained with most application equipment early in the season beforethecanopy developsfully. O nce the blueberry canopy has filled (midJune in southern M ichigan), uniform deposition becomes more difficult to obtain. The two sprayers tested here had different strengthsand weaknesses.
Fig. 6. Spray coverage (percent of surface area of card targets) in different positions in 'J ersey' blueberry canopies following treatment with an airblast sprayer driven down each row middle or alternate row middles on two dates. Data are means across three pruning treatments. LSD value refers to comparisons across spray treatment, date, and position.

percentage and uniformity of coverage, and pesticide efficacy are not understood, and likely vary with the pesticide and target organism. The blueberry maggot fly is a very mobile pest, so high uniformity of coverage (low cv) may not be necessary for control sinceadultsmay contact spray droplets even if only some surfaces are treated. This pest may even be controlled if overall coverage is low in some positions in the bush. In contrast, control of less mobile pests, such as the blueberry aphid (Illinoia pepperi $M$ acGillivray), may require high percent coverage in all positions in the bush, but thorough coverage on all sides of leaves and fruit (low cv) may not be necessary. The control of some fungal pathogens with nonsystemic fungicides may require the highest overall coverage and uniformity.

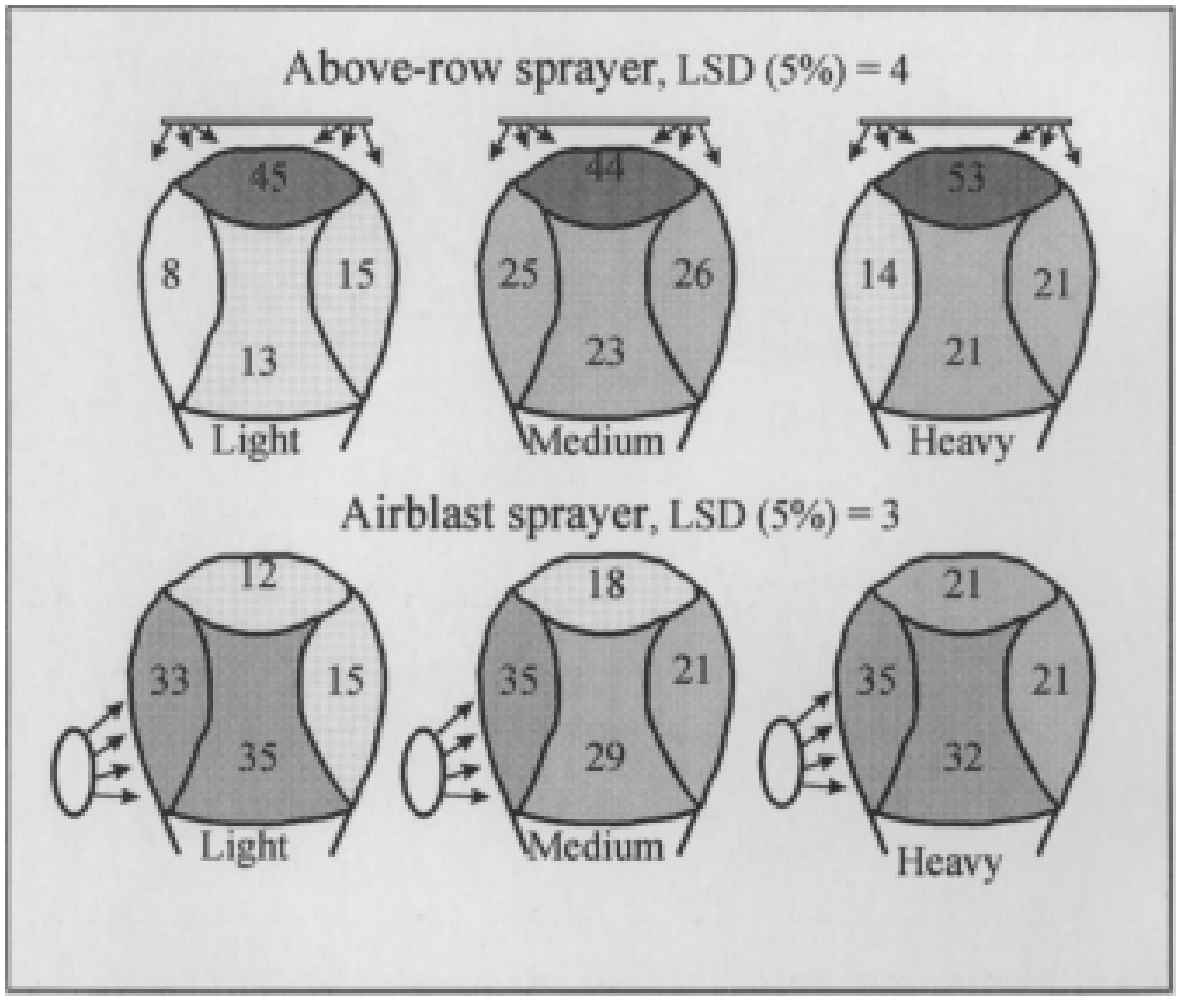

Fig. 7. E ffect of pruning severity on spray coverage (percent of surface area of card targets) in different positions in 'J ersey' blueberry canopies following treatment with above-row and airblast sprayers. D ata are means of four treatment dates between $13 \mathrm{M}$ ay (pink bud) and $11 \mathrm{~J}$ uly (green fruit). LSD values refers to comparisons across pruning treatment and position. 

severity on the coefficients of variation among the 16 measurements of percent coverage on card targets.

\begin{tabular}{|c|c|c|}
\hline \multirow[b]{2}{*}{ Parameter } & \multicolumn{2}{|c|}{ C oefficient of variation } \\
\hline & Airblast sprayer & Above-row sprayer \\
\hline \multicolumn{3}{|l|}{ Time } \\
\hline 13 M ay & $70 a^{2}$ & 77 a \\
\hline 29 M ay & 70 a & 76 a \\
\hline 3 July & $101 \mathrm{~b}$ & $94 \mathrm{~b}$ \\
\hline 11 July & $104 \mathrm{~b}$ & 94 \\
\hline Significance & $* * *$ & $* * *$ \\
\hline \multicolumn{3}{|l|}{ Position } \\
\hline Top & $89 \mathrm{~b}$ & 63 a \\
\hline Bottom & $96 \mathrm{c}$ & $99 \mathrm{c}$ \\
\hline N ear/ east & 76 a & $88 \mathrm{~b}$ \\
\hline Far/ west & 82 a & $92 \mathrm{~b}$ \\
\hline Significance & $* *$ & $* * *$ \\
\hline \multicolumn{3}{|l|}{ Pruning } \\
\hline Light & 87 & $96 \mathrm{c}$ \\
\hline M oderate & 84 & $77 \mathrm{a}$ \\
\hline H eavy & 86 & $84 \mathrm{~b}$ \\
\hline Significance & ns & $* *$ \\
\hline
\end{tabular}

zM eans in columns separated by LSD ( $P=0.05)$.

${ }_{N s, * *, * * *} N$ onsignificant or significant $F$ test at $P \leq 0.001$ or 0.01 , respectively.

The above-row sprayer provided excellent coverage in the top of the bush, but coverage in the bottom and on the sides was poor late in the season. The airblast sprayer resulted in high coverage in the bottom of the bush and on the side facing the sprayer, but coverage was poor later in the season on the sideoppositethesprayer and in the top of the bush. Operating the airblast sprayer between each row rather than alternate row middles, increased coverageand uniformity, but al so increased treatment time and may result in more fruit damage.

\section{Literature cited}

Bristow, P.R. and G.E. Windom. 1998. Epidemiology of alternaria fruit rot in the Pacific Northwest. Proc. 8th N. Amer. Blueberry Res. Ext. Work. Conf. Wilmington, N.C., 27-29 M ay.

Ferree, D.C. and F.R. H all. 1980. C anopy development, light and spray penetration in Golden Delicious trees in four management systems. Acta H ort. 114:91-99.

Gough, R.E., V.G. Shutak, and R.L. H auke. 1978. Growth and development of highbush blueberry. I. Vegetative growth. J. Amer. Soc. H ort. Sci. 103:9497.

H all, F.R. 1991. Influence of canopy geometry in spray deposition and I PM . H ortScience 26:1012-1017.
H anson, E., J. H ancock, D. Ramsdell, A. Schilder, G. VanEe, and R. Ledebuhr. 1999. Sprayer type and pruning affect the incidence of blueberry fruit rots. $\mathrm{H}$ ortScience (in press).

H artung, J.S., C.L. Burton, and D.C. Ramsdell. 1981. Epidemiological studies of blueberry anthracnosedisease caused by Colletotrichum gloeosporioides Phytopathology 71:449-453.

H offman, W.C. and M. Salyani. 1996. Spray deposition on citrus canopies under different meteorological conditions. T rans. Amer. Soc. Agr. Eng. 39:17-22.

Kirk, I.W., L.F. Bouse, J.B. Carlton, E. Franz, and R.A. Stermer. 1992. Aerial spray deposition in cotton. Trans. Amer. Soc. Agr. Eng. 35:1393-1399.

Ramsdell, D.C. 1989. Blueberry diseases in M ichigan. M ich. State U niv. Ext. Bul. E-1731.

Ramsdell, D.C. 1992. N ematode and diseasemanagement, p. 76-94. In: M .P. Pritts and J.F. $\mathrm{H}$ ancock (eds.). $\mathrm{H}$ ighbush blueberry production guide. N ortheast Reg. Agr. Eng. Serv., Cornell U niv., Ithaca, N.Y.

Siefker, J.A. and J .F. H ancock. 1987. Pruning effects on productivity and vegetative growth in the highbush blueberry. $\mathrm{H}$ ortScience 22:210-211.

U.S. D epartment of Agriculture, $\mathrm{N}$ ational Agricultural Statistics Service. 1998. Agricultural chemical usage 1997 fruits summary. Bul. Agr. Chem. 1(98). 